\title{
Ikeh, Lesor
}

\section{The inhibition performance of mono-ethylene glycol on corrosion rate of $x-80$ grade} carbon steel in saturated brine environment.

\author{
nda_sor@yahoo.com
}

Department of Petroleum and Gas Engineering,

University of Port Harcourt, Nigeria.

This article is covered and protected by copyright law and all rights reserved exclusively by the Centre for Petroleum, Pollution Control and Corrosion Studies.

$$
\text { (CEFPACS) Consulting Limited. }
$$

Electronic copies available to authorised users.

The link to this publication is https://ajoeer.org.ng/otn/ajoeer/qtr-1/2020/03 


\title{
The Inhibition Performance of Mono-Ethylene Glycol on Corrosion Rate of X-80 Grade
}

\section{Carbon Steel in Saturated Brine Environment.}

\author{
${ }^{1}$ Ikeh, L and ${ }^{\mathbf{2} D u n e, ~ K . K ~}$ \\ ${ }^{I}$ Department of Petroleum and Gas Engineering, University of Port Harcourt, Nigeria. \\ ${ }^{2}$ Department of Petroleum Engineering, Rivers State University, Nkpolu, Port Harcourt. \\ Corresponding Author: nda_sor@yahoo.com \\ [Date received: Jan 2020. Date accepted: Feb 2020]
}

\begin{abstract}
The formation/deposition of hydrate and scale in gas production and transportation pipeline has continue to be a major challenge in the oil and gas industry. Pipeline transport is one of the most efficient, reliable and safer means of transporting petroleum products from the well sites to either the refineries or to the final destinations. Acetic acid (HAc), is formed in the formation water which also present in oil and gas production and transportation processes. Acetic acid aids corrosion in pipelines and in turn aids the formation and deposition of scales which may eventually choke off flow. Most times, Monethylene Glycol (MEG) is added into the pipeline as an antifreeze and anticorrosion agent. Some laboratory experiments have shown that the MEG needs to be separated from unwanted substance such as HAc that are present in the formation water to avoid critical conditions in the pipeline. Internal pipeline corrosion slows and decreases the production of oil and gas when associated with free water and reacts with $\mathrm{CO}_{2}$ and organic acid by lowering the integrity of the pipe.
\end{abstract}

In this study, the effect of Mono-Ethylene Glycol (MEG) and Acetic acid (HAc) on the corrosion rate of $X-80$ grade carbon steel in $\mathrm{CO}_{2}$ saturated brine were evaluated at $25^{\circ} \mathrm{C}$ and $80^{\circ} \mathrm{C}$ using $3.5 \% \mathrm{NaCl}$ solution in a semi-circulation flow loop set up. Weight loss and electrochemical measurements using the linear polarization resistance (LPR) and electrochemical impedance spectroscope (EIS) were used in measuring the corrosion rate as a function of HAc and MEG concentrations. The results obtained so far shows an average corrosion rate increases from 0.5 to $1.8 \mathrm{~mm} / \mathrm{yr}$ at $25^{\circ} \mathrm{C}$, and from 1.2 to $3.5 \mathrm{~mm} / \mathrm{yr}$ at $80^{\circ} \mathrm{C}$ in the presence of HAc. However, there are decrease in corrosion rate from 1.8 to $0.95 \mathrm{~mm} / \mathrm{yr}$ and from 3.5 to $1.6 \mathrm{~mm} / \mathrm{yr}$ respectively at $25^{\circ} \mathrm{C}$ and $80^{\circ} \mathrm{C}$ on addition of $20 \%$ and $80 \% \mathrm{MEG}$ concentrations to the solution. It is also noted that the charge transfer with the electrochemical measurements (EIS) results is the main corrosion controlling mechanism under the test conditions. The higher temperature led to faster film dissolution and higher corrosion rate in the presence of HAc. The EIS results also indicate that the charge transfer controlled behaviour was as a result of iron carbonate layer accelerated by the addition of different concentrations of MEG to the system.

Key words: $\mathrm{CO}_{2}$ corrosion, Carbon steel, $M E G$, HAc, Inhibition, Environment. 


\section{Introduction}

Natural gas contains about 20 to $100 \mathrm{Ibm}$ of water per MMSCF of gas, depending on the saturated point at the operating conditions. The processing and transportation of this gas in the pipeline with the presence of water are hindered by the formation hydrate and corrosion. Hydrate formation and corrosion in gas transmission pipeline leads to blockage and pipeline failure which in turn reduces gas production/transmission capacity [1]

A lot of works had been carried out on different grade of carbon steel pipeline corrosion in $\mathrm{CO}_{2}$ saturated environment, but none or little had been said to the conditions where acetic acids and MEG are present on X-80 grade carbon steel.

$\mathrm{CO}_{2}$ corrosion in the presence of HAc is known as major causes for premature failures in oil and gas pipelines that usually made of carbon steel [9]. Acetic acid is often the most abundant volatile organic acids in formation water. In oilfield pipelines with low partial pressure of $\mathrm{CO}_{2}\left(\mathrm{pCO}_{2}\right)$, the corrosion issues are easily managed, but when small amounts of HAc are present, the corrosivity of the brine can change dramatically [10]. It has been shown experimentally that the total quantity of organic acids in produced water in oil and gas system ranging between 500-3000 ppm of which HAc contributes about 50-90\% of organic acids [11]. Also, a systematic investigation of field data showed that undissociated HAc concentration higher than 0.1-1 mM was a critical factor for $\mathrm{CO}_{2}$ corrosion [10]. Garsany et al. [12] in their study proposed that the role of acetic acid is to act as a reactant in the cathodic process which could have a significantly higher rate than the reduction of protons or carbonic acid in oilfield conditions. The three main cathodic reactions involving HAc proposed by Garsany et al are [12]:

$$
\begin{gathered}
2 \mathrm{HAc}+2 e^{-} \rightarrow 2 \mathrm{Ac}^{-}+\mathrm{H}_{2} \\
2 \mathrm{H}^{+}+2 e^{-} \rightarrow \mathrm{H}_{2} \\
2 \mathrm{H}_{2} \mathrm{CO}_{3}+2 \mathrm{e}^{-} \\
\rightarrow \mathrm{H}_{2}+2 \mathrm{HCO}_{3}^{-}
\end{gathered}
$$

The reaction mechanism and kinetics of the iron dissolution reaction with the overall reaction of equation (3) are affected by $\mathrm{HAc}, \mathrm{pCO}_{2}$, and $\mathrm{pH}[13]$.

Dugstad [14] and Gunaltun et al. [15] reported some results from field observations and laboratory investigations that the presence of HAc may induce a detrimental effect on the overall corrosion rate and the pitting morphology in sweet systems. Field experienced has also shown that HAc is a key factor in the localized top-of-line corrosion attacks in gascondensate to pipeline [16]. The presence of HAc also tend to solubilize the dissolving iron 
ions and suppress $\mathrm{FeCO}_{3}$ or oxide film formation, which can passivate the steel surface [17]. Iron carbonate scale $\left(\mathrm{FeCO}_{3}\right)$ that forms on the carbon steel in $\mathrm{CO}_{2}$ environments is a frequent concern in the oil and gas production and transportation industry. The $\mathrm{FeCO}_{3}$ film can slow the corrosion process by presenting a diffusion barrier for the species involve and covering up a portion of the steel surface as well as preventing the underlying steel from further dissolution. The steel surface corrodes under the film continuously creating a void between the film and the steel surface [18]

In a similar way, Gulbrandsen et al [2] observed that MEG altered the anodic half reaction of the corrosion process (dissolution of iron). They related the results to the possible adsorption of MEG on the steel surface. The corrosion rate of steel in the presence of MEG can be lower compared to that without MEG [2, 3]. De Waard and Milliams [3] demonstrated the addition of glycol to wet gas pipeline influenced $\mathrm{CO}_{2}$ corrosion by lowering the dew point of water and consequently could reduce the severity of Top-of-the-line corrosion. They further reported that the corrosion rate at the bottom of the line decreases when glycol mixes with the water phase [1-5]. The influence of other parameters such as $\mathrm{O}_{2}, \mathrm{H}_{2} \mathrm{~S}$ in continuation with MEG had been carried out, but the effects with HAc are yet to be studied [2, 4-6].

Besides, the use of $\mathrm{pH}$ stabilization in a MEG-containing system has successfully been implemented in the multiphase transportation of natural gas $[1,4,7]$. The $\mathrm{pH}$ stabilization often works by reducing the cathodic reaction of the corrosion of steel while encouraging the formation of protective iron carbonate on the surface of the carbon steel pipeline. When formation water is produced from the well, $\mathrm{pH}$ stabilization become undesirable method for preventing corrosion as other unwanted scale may form along the pipeline $[3,8]$.

As can be observed, different works had been conducted on carbon steel in $\mathrm{CO}_{2}$ saturated brine, but none or little had been heard on how MEG affect the $\mathrm{CO}_{2}$ corrosion in the presence of HAc. Hence, this paper examines the corrosion rate of X-80 grade carbon steel under the influence of different concentrations of $\mathrm{HAc}$ and $\mathrm{MEG}$ in $\mathrm{CO}_{2}$ saturated environment

\section{Experimental Procedure}

The experiments were performed in a mini circulation flow loop. A peripheral pump circulates the test solution from the reservoir to the test cell. A small diameter pipe maintained a constant liquid volume flow in the cell. The reservoir tank and the test cell were continuously purged with $\mathrm{CO}_{2}$ to removed oxygen completely from the test solution. Once de-oxygenation has been achieved, the required amount of HAc and MEG were added at the start of every experiment. The temperatures were controlled by means of a heating plate with a temperature sensor in the cell. The $\mathrm{pH}$ of the solution was adjusted to the desired value throughout the experiments by adding sodium bicarbonate $\left(\mathrm{NaHCO}_{3}\right)$ or hydrochloric acid $(\mathrm{HCl})$ as needed. 


\section{Test set up and procedures}

The test specimens used throughout this study are the $\mathrm{X}-80$ grade carbon steel having a surface area of $8.11 \mathrm{~cm}^{2}$ and a circular hole toward the top end (For the weight loss experiment). A copper wire $0.02 \mathrm{~mm}$ diameter was spot welded and used on the test coupon to ensure electrical contact between the coupon and the electrolyte. The test coupons were suspended in the test solution by passing a plastic wire through the coupon and the wire was hung to a plastic rod held in place of the glass cell top holes. Prior to introduction into the test cell, the test coupon were successively ground with 240,600 and $800 \mathrm{SiC}$ grit paper and polished with $1200 \mathrm{SiC}$ paper.it was then cleaned with acetone, rinsed with distilled water and dried. The general composition of $\mathrm{X}-80$ grade carbon steel samples used in this work is given in Table 1

Table 1: Chemical composition of X-80 grade carbon steel, wt. \%.

\begin{tabular}{|l|l|l|l|l|l|l|l|l|l|l|l|}
\hline Comp. & $\mathrm{C}$ & $\mathrm{Si}$ & $\mathrm{Mn}$ & $\mathrm{S}$ & $\mathrm{P}$ & $\mathrm{Sn}$ & $\mathrm{Cr}$ & $\mathrm{Ni}$ & $\mathrm{Mo}$ & $\mathrm{Cu}$ & $\mathrm{Al}$ \\
\hline $\begin{array}{l}\text { Val. } \\
\%\end{array}$ & 0.08 & 0.25 & 1.54 & 0.001 & 0.019 & 0.008 & 0.04 & 0.03 & 0.01 & 0.12 & 0.038 \\
\hline
\end{tabular}

Four test solutions were prepared. The first test solution was prepared with $3.5 \% \mathrm{wt}$. sodium chloride $(\mathrm{NaCl})$ as the blank solution without HAc and MEG. The second test solution was prepared using 3.5\% $\mathrm{NaCl}$ solution and HAc concentrations of $500 \mathrm{ppm}, 1000 \mathrm{ppm}$ and 2000 ppm respectively. The third test solution was prepared using 3.5\% $\mathrm{NaCl}$ solution, 500,1000 , $2000 \mathrm{ppm}$ of HAc and $20 \%$ MEG concentration, while the fourth test solution was prepared using $3.5 \% \mathrm{NaCl}, 500,1000,2000 \mathrm{ppm}$ of HAc and $80 \%$ MEG c oncentrations. Table 2 shows the test matrix for this study.

Table 2: Compositions of the text matric used for the experiments

\begin{tabular}{|l|l|}
\hline Parameters & Values \\
\hline Test solution & $3.5 \%$ wt. NaCl \\
\hline Test material & $\mathrm{X}-80$ grade carbon steel \\
\hline Partial pressure of $\mathrm{CO}_{2}[\mathrm{bar}]$ & 0.54 \\
\hline MEG concentrations $[\%]$ & {$[20,80]$} \\
\hline $\mathrm{pH}$ & 6.6 \\
\hline Temperature $\left({ }^{\circ} \mathrm{C}\right)$ & {$[25,80]$} \\
\hline $\mathrm{C}_{\mathrm{HAc}}(\mathrm{ppm})$ & {$[0,1000,2000]$} \\
\hline Surface area $\left(\mathrm{cm}^{2}\right)$ & 8.11 \\
\hline Test method & {$[\mathrm{WL}, \mathrm{LPR}$ and EIS] } \\
\hline
\end{tabular}




\section{Measurement Techniques}

Weight loss measurement was performed on the $\mathrm{X}-80$ carbon steel samples in all the test solutions at temperatures of $25^{\circ} \mathrm{C}$ and $80^{\circ} \mathrm{C}$ as outlined in ASTM G1. The weight loss is determined and the corrosion rate calculated using Equation 4:

$$
\mathrm{CR}=\frac{\mathrm{WL}(\mathrm{g})}{\rho \times \mathrm{t} \times \mathrm{A}} \times \mathrm{K}\left(\frac{\mathrm{mm}}{\mathrm{yr}}\right)
$$

Where:

$\mathrm{CR}=$ corrosion rate, $\mathrm{mm} / \mathrm{yr}$,

$\rho=$ density of the material, $7.86 \mathrm{~g} / \mathrm{cm}^{3}$

$\mathrm{WL}=$ weight loss, grams,

$\mathrm{t}=\quad$ the exposed time, $\mathrm{hr}$

$\mathrm{A}=$ the exposed coupon surface area, $\mathrm{cm}^{2}$,

$\mathrm{K}=$ conversion factor, $8.76 \times 10^{4}$

The electrochemical measurements were carried out using a commercial potentiostat. A three-electrode configuration was used in every measurement. The carbon steel sample was used as the working electrode, while the $\mathrm{Ag} / \mathrm{AgCl}$ wire was used as reference electrode. The linear polarization curves were obtained in the potential range of -10 to $+10 \mathrm{mV}$ (vs. $\mathrm{E}_{\text {corr }}$ ) with a scan rate of $0.1 \mathrm{mV} / \mathrm{s}$. Electrochemical Impedance measurements were also performed with an excitation of $10 \mathrm{mV}$ sinusoidal sign in a frequency range from $10 \mathrm{KHz}$ to $10 \mathrm{mHz}$ and the signal amplitude were fixed at 7 points/decade.

\section{Results and Discussion}

\section{Weight Loss with HAc}

The variations of the average weight loss per unit area as a function of time in the presence of HAc are shown below. The weight loss of the first test solution $(3.5 \% \mathrm{wt}$. $\mathrm{NaCl}$ without HAc and MEG) and the second test solution $(3.5 \% \mathrm{NaCl}$ with $1000 \mathrm{ppm}$ and $2000 \mathrm{ppm}$ of HAc concentrations and without MEG) were presented in Figures $1 \& 2$ at temperatures of $25^{\circ} \mathrm{C}$ and $80^{\circ} \mathrm{C}$. From the graph (Figures 1 and 2), it shows an increased in weight loss over time as the concentrations of HAc increases. The average weight loss of the $\mathrm{X}-80$ grade carbon steel increased at both temperatures, although higher at $80^{\circ} \mathrm{C}$ than at $25^{\circ} \mathrm{C}$. It is observed that the high weight loss at $80^{\circ} \mathrm{C}$ is due to the fast reaction rate that occurs at higher temperatures. Similarly, at this temperature $\left(80^{\circ} \mathrm{C}\right)$, it is assumed that a protective $\mathrm{FeCO}_{3}$ corrosion films are formed and remain protective in the presence of HAc provided the super-saturation is high enough. Table 3 show the summary of the average weight loss per unit area for the X-80 grade carbon steel used for the experiments at $25^{\circ} \mathrm{C}$ and $80^{\circ} \mathrm{C}$ in the present of HAc. 


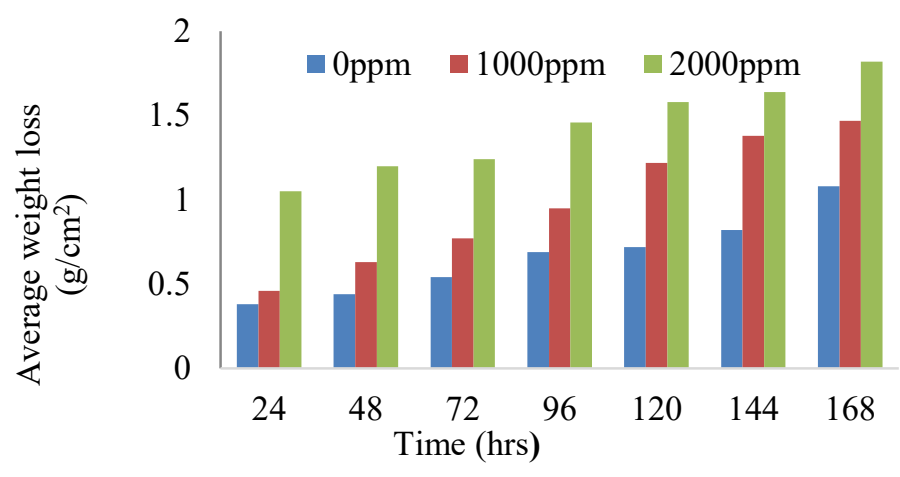

Fig 1: Average weight loss as a function time for $\mathrm{X}-80$ grade carbon steel in $3.5 \%$ wt. solution at $25^{\circ} \mathrm{C}$.

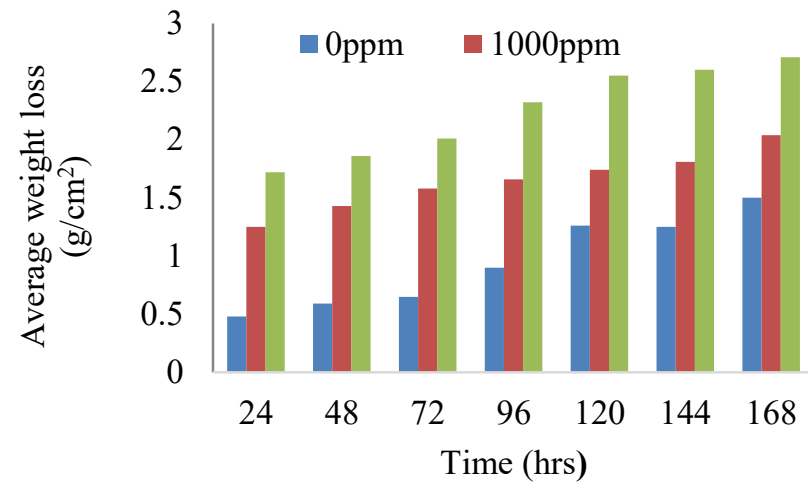

Fig 2: Average weight loss as a function time for $\mathrm{X}$ 80 grade carbon steel in $3.5 \% \mathrm{wt}$. solution at $80^{\circ} \mathrm{C}$.

Table 3: Summary of average weight loss a function of time for X-80 grade carbon steel in the presence of $\mathrm{HAc}$ at $25^{\circ} \mathrm{C}$ and $80^{\circ} \mathrm{C}$.

\begin{tabular}{lllllll}
\hline T(hrs) & & \multicolumn{5}{c}{ Weight loss per unit area $\left(\mathbf{g} / \mathbf{c m}^{\mathbf{2}}\right)$} \\
\hline & & $\mathbf{T}=\mathbf{2 5}^{\mathbf{0}} \mathbf{C}$ & \multicolumn{3}{c}{$\mathbf{T}=\mathbf{8 0}^{\mathbf{0}} \mathbf{C}$} \\
\hline 24 & Blank & $1000 \mathrm{ppm}$ & $2000 \mathrm{ppm}$ & Blank & $1000 \mathrm{ppm}$ & $2000 \mathrm{ppm}$ \\
48 & 0.38 & 0.46 & 1.05 & 0.48 & 1.25 & 1.72 \\
72 & 0.44 & 0.63 & 1.2 & 0.59 & 1.43 & 1.86 \\
96 & 0.54 & 0.77 & 1.24 & 0.65 & 1.58 & 2.01 \\
120 & 0.69 & 0.95 & 1.46 & 0.9 & 1.66 & 2.32 \\
144 & 0.72 & 1.22 & 1.58 & 1.26 & 1.74 & 2.55 \\
168 & 0.82 & 1.38 & 1.64 & 1.25 & 1.81 & 2.6 \\
\hline
\end{tabular}




\section{Weight Loss with HAc and MEG}

Figures 3 and 4 show results of average weight loss as a function of time for carbon steel in third test solution $(3.5 \% \mathrm{NaCl}, 20 \%$ MEG concentration with $1000 \mathrm{ppm}$ and $2000 \mathrm{ppm}$ concentrations of $\mathrm{HAc}$ ) and fourth test solution $(3.5 \% \mathrm{NaCl}, 80 \% \mathrm{MEG}$ concentration with $1000 \mathrm{ppm}$ and $2000 \mathrm{ppm}$ concentrations of $\mathrm{HAc}$ ) at $25^{\circ} \mathrm{C}$ and $80^{\circ} \mathrm{C}$. As can be seen, the addition of $20 \%$ and $80 \%$ MEG concentrations to the solutions has a significant influence on the weight loss of the $\mathrm{X}-80$ carbon steel materials. In Figure 3, it is quite obvious that the weight loss reduced drastically from $1.80 \mathrm{~g} / \mathrm{cm}^{2}$ to $0.77 \mathrm{~g} / \mathrm{cm}^{2}$ and $1.98 \mathrm{~g} / \mathrm{cm}^{2}$ to $0.83 \mathrm{~g} / \mathrm{cm}^{2}$ with the addition of $20 \%$ MEG to $1000 \mathrm{ppm}$ and $2000 \mathrm{ppm}$ concentrations of HAc at $25^{\circ} \mathrm{C}$. Similarly, Figure 4 show the average weight loss over 168 hours reduced approximately from $3.50 \mathrm{~g} / \mathrm{cm}^{2}$ to $0.81 \mathrm{~g} / \mathrm{cm}^{2}$, and from $3.58 \mathrm{~g} / \mathrm{cm}^{2}$ to $0.93 \mathrm{~g} / \mathrm{cm}^{2}$ on addition of $50 \%$ MEG to different concentration of HAc. The decrease in average weight loss observed in Figure 3 and Figure 4 are attributed to the reduction in $\mathrm{pH}$ of the solution on addition of the MEG solution. The summary of the average weight loss for the carbon steel in the presence of HAc and on addition of MEG concentrations are shown in Table 4.

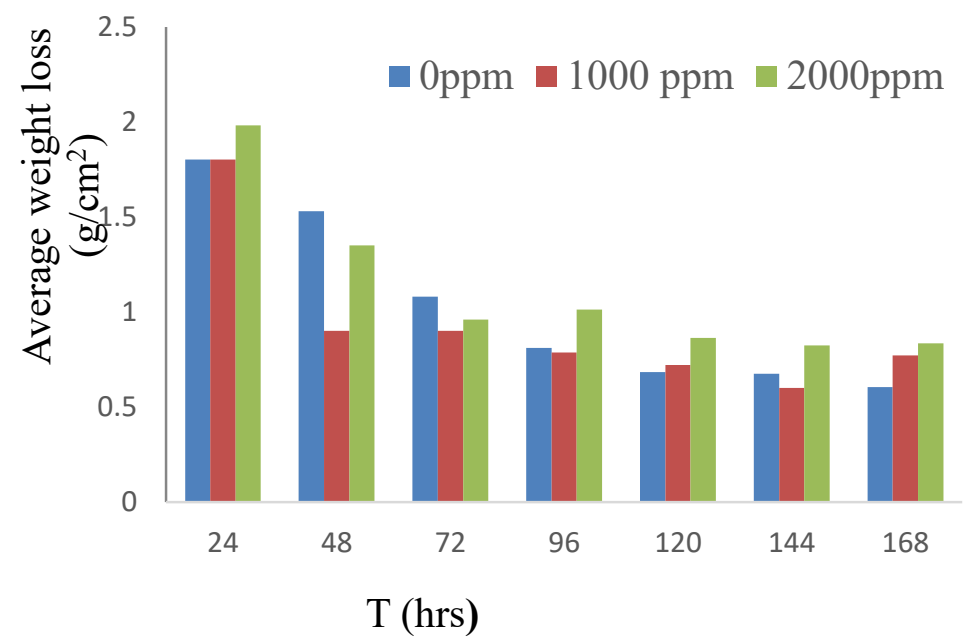

Fig 3: Average weight loss as a function time for $\mathrm{X}-80$ grade carbon steel in $3.5 \%$ wt. solution with $20 \% \mathrm{MEG}$ at $25^{\circ} \mathrm{C}$

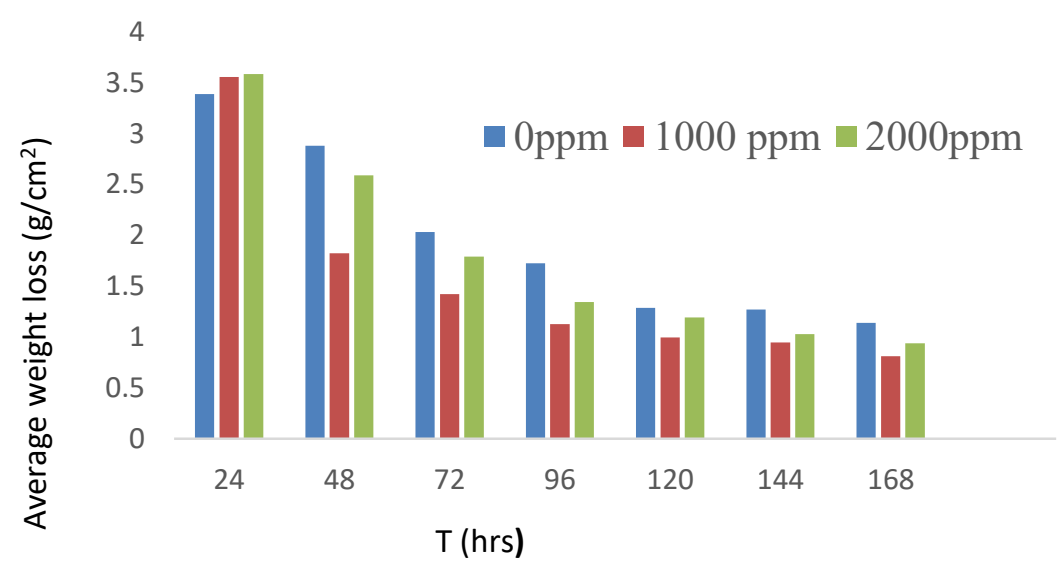


Fig 4: Average weight loss as a function time for $\mathrm{X}-80$ grade carbon steel in $3.5 \%$ wt. solution with $20 \% \mathrm{MEG}$ at $80^{\circ} \mathrm{C}$

Table 4: Summary of average weight loss as a function of time for $\mathrm{X}-80$ grade carbon steel material in the presence of HAc and MEG at $25^{\circ} \mathrm{C}$ and $80^{\circ} \mathrm{C}$.

\begin{tabular}{|c|c|c|c|c|c|c|}
\hline \multirow[t]{3}{*}{ Time (hrs) } & \multicolumn{6}{|c|}{ Weight loss per unit area $\left(\mathrm{g} / \mathrm{cm}^{2}\right)$} \\
\hline & \multicolumn{2}{|c|}{$\mathrm{T}=25^{\circ} \mathrm{C}, \mathbf{2 0} \% \mathrm{MEG}$} & \multicolumn{4}{|c|}{$\mathrm{T}=80^{\circ} \mathrm{C}, 20 \%$ MEG } \\
\hline & Blank & $1000 \mathrm{ppm}$ & $2000 \mathrm{ppm}$ & Blank & $1000 \mathrm{ppm}$ & $2000 \mathrm{ppm}$ \\
\hline 24 & 1.80 & 1.80 & 1.98 & 3.17 & 3.55 & 3.58 \\
\hline 48 & 1.53 & 0.90 & 1.35 & 3.17 & 1.82 & 2.58 \\
\hline 72 & 1.08 & 0.90 & 0.96 & 3.17 & 1.42 & 1.79 \\
\hline 96 & 0.81 & 0.78 & 1.01 & 2.64 & 1.12 & 1.34 \\
\hline 120 & 0.68 & 0.72 & 0.86 & 2.74 & 0.99 & 1.19 \\
\hline 144 & 0.67 & 0.60 & 0.82 & 2.50 & 0.94 & 1.02 \\
\hline 168 & 0.60 & 0.77 & 0.83 & 2.26 & 0.81 & 0.93 \\
\hline
\end{tabular}

\section{Linear Polarization Resistance (LPR)}

The effect of HAc, $20 \%$ and $80 \%$ MEG on the corrosion rate of carbon steel in $\mathrm{CO}_{2}$ saturated environment were also evaluated using the LPR measurement technique. Figures 5 and 6 show the variations of measured corrosion rates of steel samples in all the test solutions at $25^{\circ} \mathrm{C}$ and $80^{\circ} \mathrm{C}$

In Figure 5, the corrosion rate increase steadily as the concentrations of the acetic acid were increased for a while and thereafter remain steady for the remaining period of the experiment. At $80^{\circ} \mathrm{C}$ (Figure 6), the corrosion rate increases and thereafter decreases and remain steady throughout the remaining period of the experiment. Though, protective films forms at both temperatures, it is more adherent and protective at $80^{\circ} \mathrm{C}$ compared to $25^{\circ} \mathrm{C}$. Obviously, it is observed that the $\mathrm{Fe}^{2+}$ concentration affects the rate of film formation and not the protectiveness as reported by Nafday et al [9]. Also, it is noted that charge transfer control is the main corrosion controlling mechanism under the test conditions. The higher temperature led to faster film dissolution and higher corrosion rate in the presence of HAc. However, the increased corrosion rate is due to the effect of undissociated HAc on the catholic reactions of the corrosion process. This shows that larger fraction of the $\mathrm{FeCO}_{3}$ formed in the corrosion process are lost to the bulk solution. 


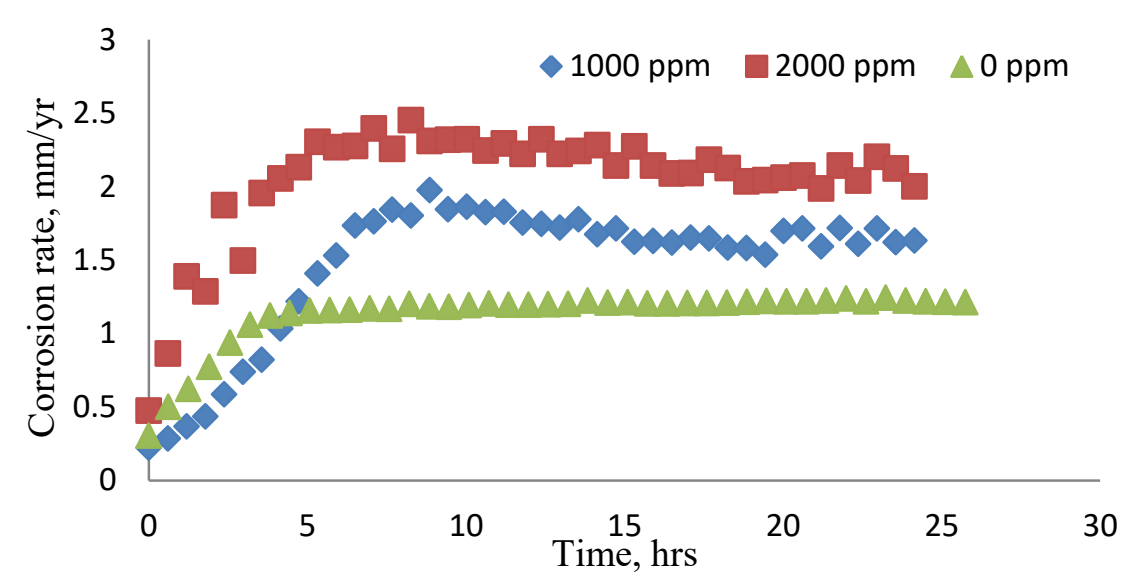

Fig 5: Measured corrosion rate as a function of time for $\mathrm{X}-80$ grade carbon steel sample in $\mathrm{CO}_{2}$ solution saturated with brine at $25^{\circ} \mathrm{C}$

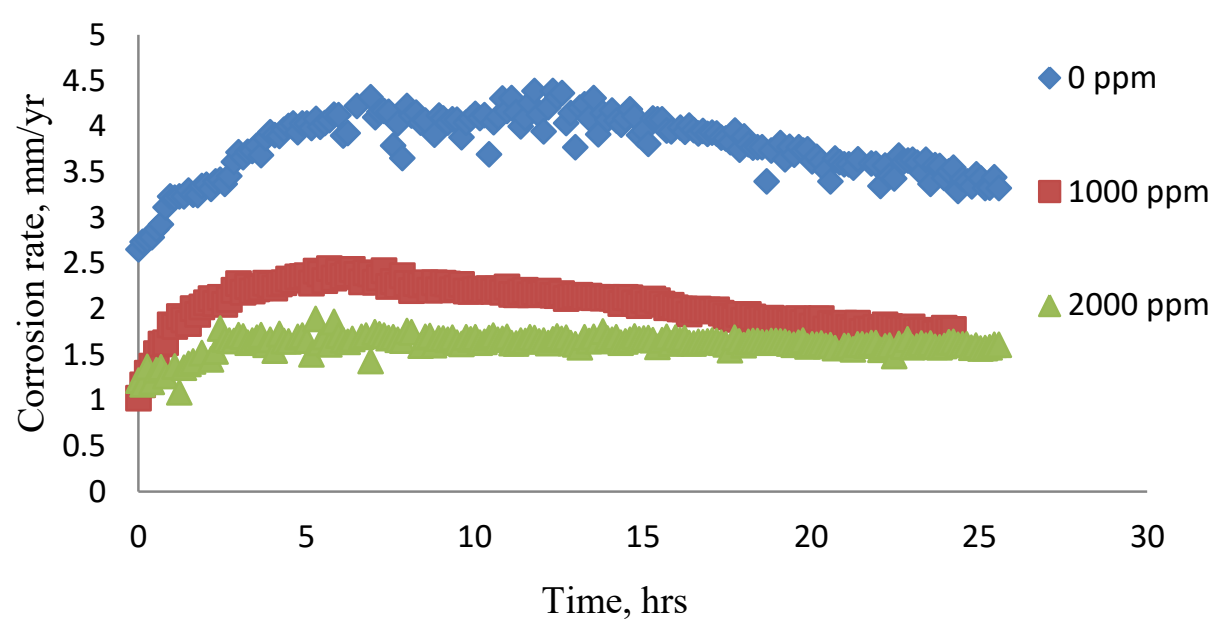

Fig 6: Measured corrosion rate as a function of time for $\mathrm{X}-80$ grade carbon steel sample in $\mathrm{CO}_{2}$ solution saturated with brine at $80^{\circ} \mathrm{C}$

Figure 7 show the variations of measured corrosion rates of steel samples in all the test solutions at $80^{\circ} \mathrm{C}$. It is observed that the addition of MEG to the solutions containing HAc reduces the corrosion rates at $80^{\circ} \mathrm{C}$. The reduction in corrosion rate is caused by $\mathrm{FeCO}_{3}$ solubility decrease with $\mathrm{MEG}$, and $\mathrm{FeCO}_{3}$ super-saturation increase in the presence of MEG. 


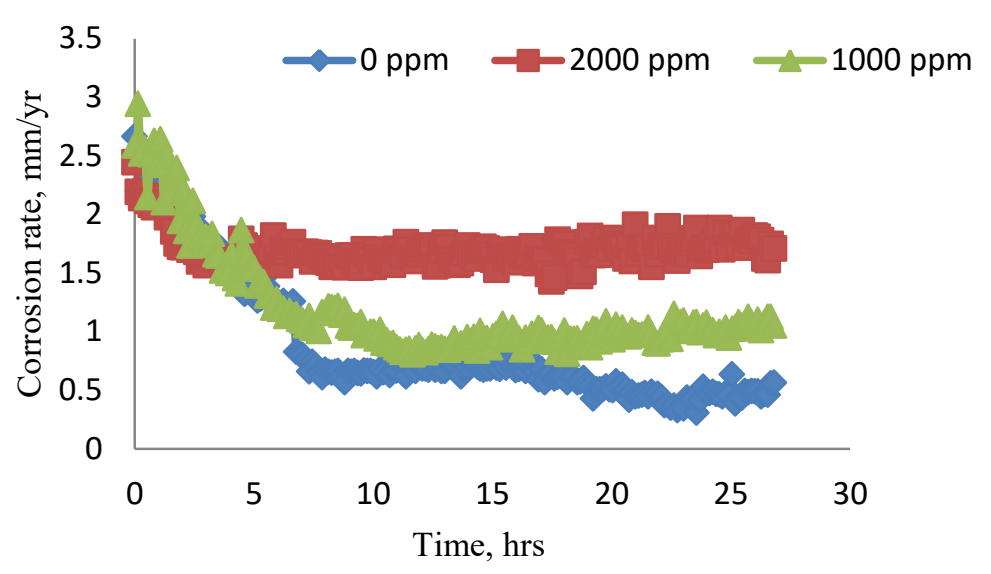

Fig 7: Measured corrosion rate as a function of time for $3.5 \% \mathrm{NaCl}$ solution saturated with brine and $20 \%$ MEG concentrations at $80^{\circ} \mathrm{C}$

\section{Electrochemical Impedance Spectroscope (EIS)}

The linear polarization resistance (LPR) measurements demonstrates only the change of dissolution of the steel surface under certain conditions, the electrochemical impedance spectroscope (EIS) was used as an alternative measurement to explain the mechanisms of electrochemical reactions that occur at the metal- electrolyte interface.

Figures 8 and 9 shows the Nyquist plots measured on the X-80 grade carbon steel in saturated $\mathrm{CO}_{2}$ environments at $25^{\circ} \mathrm{C}$ and $80^{\circ} \mathrm{C}$ with different concentrations of HAc. The graphs (Figures 8 and 9) show a large capacitive semicircle at high frequencies which is considered as the capacitance of double electrode layer between the $\mathrm{FeCO}_{3}$ films and the solutions. With the addition of more concentrations of HAc, the high frequency semicircle decreases in size. The decrease in size shows an increase in corrosion rate as well as decrease in the protectiveness of $\mathrm{FeCO}_{3}$ layer. It is noted that when the protective layer is completely impact, the corrosion is controlled by a diffusion transfer process, and when there are pores in the protective layers, a charge transfer process at the steel-layer interface occurs.

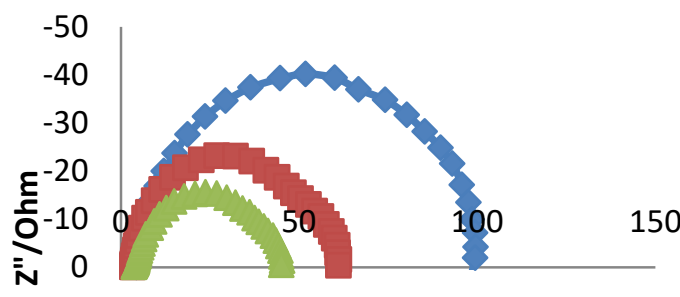

Z/Ohm

Fig 8: Nyquist plot for $\mathrm{X}-80$ grade carbon steel sample in $3.5 \%$ wt $\mathrm{NaCl}$ solution at $25^{\circ} \mathrm{C}$ 


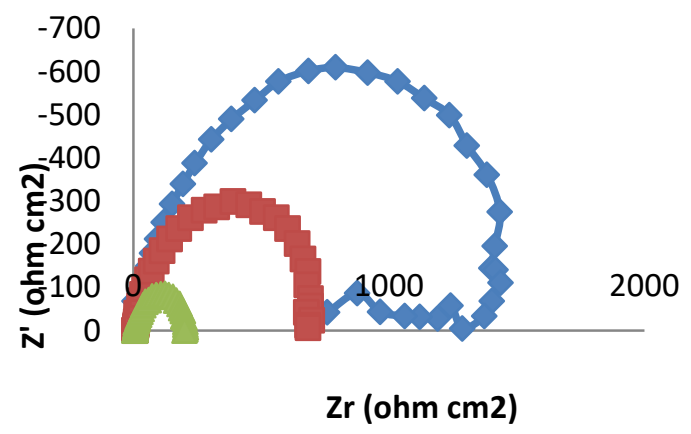

Fig 9: Nyquist plot for $\mathrm{X}-80$ grade carbon steel sample in $3.5 \%$ wt $\mathrm{NaCl}$ solution at $80^{\circ} \mathrm{C}$

Similarly, Figures 10 and 11 shows the EIS results of HAc in the presence of MEG. As can be seen, addition of $20 \%$ and $80 \%$ MEG increases the solution resistance of HAc in solution of $3.5 \% \mathrm{NaCl}$. This means that the charge resistance increases with the MEG concentrations. This is in agreement with the results obtained measured using the linear polarization resistance as shown in Figure 7.

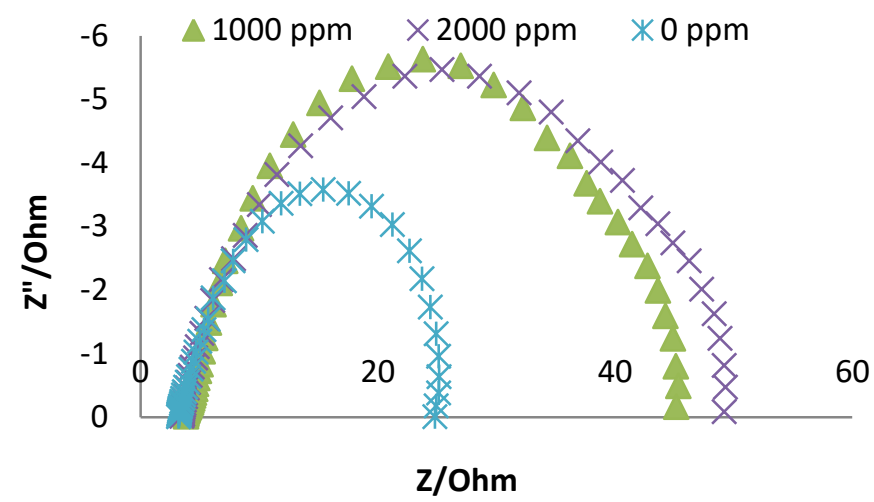

Fig 10: Nyquist plot for X-80 grade carbon steel sample in $3.5 \% \mathrm{wt}$ $\mathrm{NaCl}$ solution at with $\mathrm{HAC}$ and $20 \% \mathrm{MEG}$ at $25^{\circ} \mathrm{C}$ 


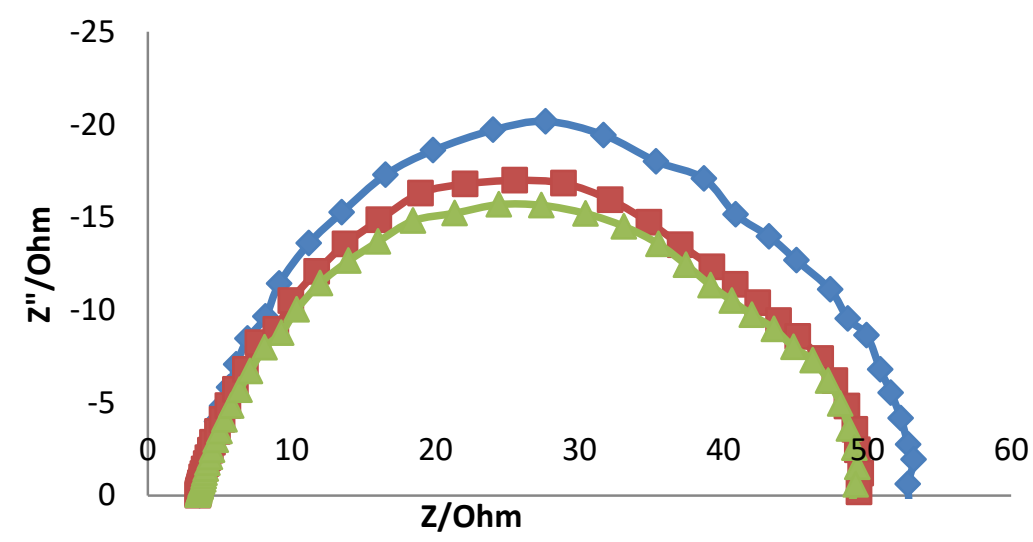

Fig 11: Nyquist plot for $\mathrm{X}-80$ grade carbon steel sample in $3.5 \% \mathrm{wt}$ $\mathrm{NaCl}$ solution with $\mathrm{HAC}$ and $20 \% \mathrm{MEG}$ at $80^{\circ} \mathrm{C}$

\section{Conclusions}

An experimental study of corrosion of X-80 grade carbon steel in $\mathrm{CO}_{2}$ saturated brine in the presence of HAc and MEG has been studied. A mini circulation flow loop were used to performed an experiments at temperature of $25^{\circ} \mathrm{C}$ and $80^{\circ} \mathrm{C}$, with $\mathrm{pH}$ of $6.6,0.54$ bar of $\mathrm{CO}_{2}$ partial pressure, $20 \%$ and $80 \%$ MEG concentrations and different concentrations of HAc. The following observations were deducted:

- The average weight loss per unit area of the X-80 grade carbon steel increases steadily as the concentrations of HAC was increased. At $80^{\circ} \mathrm{C}$, the corrosion rate increases for a while before decreases when protective $\mathrm{FeCO}_{3}$ have formed. This result showed a comparable corrosion rate at both temperatures with the addition of different concentrations of HAc.

- It is also observed that addition of $20 \%$ and $80 \%$ MEG concentrations to the solution reduced the corrosion rate at both temperatures compared the corrosion rate when only HAc are present

- The electrochemical measurements have shown that the corrosion rate increases with increased in concentration of HAc, and decreases with the increment of exposition time. However, this can be attributed to the formation of iron carbonate film on the surface of the steel sample.

- The Nyquist plots of the EIS measurement have shown that the diameter of the depressed semicircle decreased as the concentrations of the HAc increases, and the capacitive semicircle sizes also decreased on addition of $20 \%$ and $80 \%$ MEG to the solution. 


\section{Acknowledgments.}

The authors would like to thank the University of Salford, Manchester and the University of Port Harcourt for their support for this work

\section{References}

[1] Gonzalez, J.J., M.E. Alfonso, and G. Pellegrino, Corrosion of Carbon Steels in Monoethylene Glycol. NACE International.

[2] Gulbrandsen, E. and J.H. Morard, Why Does Glycol Inhibit $\mathrm{CO}_{2}$ Corrosion? NACE International.

[3] de Waard, C., U. Lotz, and D.E. Milliams, Predictive Model for $\mathrm{CO}_{2}$ Corrosion Engineering in Wet Natural Gas Pipelines. Corrosion, 1991. 47(12): p. 976-985.

[4] Ivonye, I., et al., Corrosion Study of Carbon Steel in the Presence of Monoethylene Glycol (MEG) and Corrosion Inhibitors in Acid. NACE International.

[5] Kvarekval, J., S. Olsen, and S. Skjerve, The Effect of $\mathrm{O}_{2}$ on $\mathrm{CO}_{2}$ Corrosion in pH Stabilized Gas/Condensate Pipelines. NACE International.

[6] Kvarekvål, J. and A. Pedersen, An Electrochemical Study of Corrosion Inhibition of Carbon Steel in Sour Glycol Solutions. NACE International.

[7] Elhady, A.A.A., Operating Experiences of DEG and MEG for Hydrate and Dewpoint Control in Gas Production Offshore Mediterranean. German National Library of Science and Technology, 2006.

[8] Dugstad, A., M. Seiersten, and R. Nyborg, Flow Assurance of pH Stabilized Wet Gas Pipelines. NACE International.

[9] George, K. and S. Nesic, Investigation of carbon dioxide corrosion of mild steel in the presence of acetic acid - part 1: Basic mechanisms. Corrosion Science, 2007(63): p. 178-86.

[10] Crolet, J.-L. and M.R. Bonis, Prediction of the Risks Of $\mathrm{CO}_{2}$ Corrosion in Oil and Gas Wells. SPE Production Engineering, 1991. 6(4): p. 449-453.

[11] Gunaltun, Y. and L. Payne, A New Technique for the Control of Top of the Line Corrosion: TLCC-PIG. 2003, NACE International. 
[12] Garsany, Y., D. Pletcher, and B. Hedges, "Speciation and electrochemistry of brines containing acetate ion and carbon dioxide". J. Electronal. Chemistry,, 2002. 538-539: p. 285.

[13] Crolet, J.L., A. Dugstad, and N. Thevenot, Role of Free Acetic Acid on the $\mathrm{CO}_{2}$ Corrosion of Steels. 1999, NACE International.

[14] Dugstad, A., Fundamental Aspects of $\mathrm{CO}_{2}$ Metal Loss Corrosion - Part 1: Mechanism. 2006, NACE International.

[15] Gunaltun, Y.M. and D. Supriyatman, Top of the Line Corrosion in Multiphase Gas Lines: A Case History. 1999, NACE International.

[16] Gunaltun, Y.M. and D. Larrey, Correlationwith calculated water condensation rates. NACE CORROSION 2000. Paper no. 71.

[17] Videm, K. and A. Dugstad, Corrosion of carbon steel in an aqueous carbon dioxide environment, Part 2: Film formation. Materials Performance, 1989: p. 46-50.

[18] Sun, W., K. Chokshi, and S. Nesic, Iron Carbonate Scale Growth and the Effect of Inhibition in $\mathrm{CO}_{2}$ Corrosion of Mild Steel. NACE International.

[19] Nafday, O. and S. Nesic, Iron Carbonate Scale Formation and $\mathrm{CO}_{2}$ Corrosion in the Presence of Acetic Acid. NACE International. 